\title{
Loss of EPCAM Expression
}

National Cancer Institute

\section{Source}

National Cancer Institute. Loss of EPCAM Expression. NCI Thesaurus. Code C163014.

A molecular abnormality indicating the absence of EPCAM protein. 